\title{
Epiphytic Orchid Diversity in UB Forest and Opportunities for Orchid Tourism Trails Development
}

\author{
Gheavanda Putri Rahadi ${ }^{1}$, Luchman Hakim ${ }^{1,2^{*}}$ \\ ${ }^{1}$ Department of Biology, Faculty of Mathematics and Natural Sciences, Brawijaya University, East Java, Indonesia \\ ${ }^{2}$ Tourism Reseach Centre, Brawijaya University, East Java, Indonesia
}

\begin{abstract}
The aims of the research were to identify epiphytic orchid diversity and host tree species for the development of orchid tourism trails as a potential tourist attraction in UB Forest. A Floristic survey and questionnaires were conducted in this study. Nine epiphytic orchids were found in UB Forest, namely Liparis viridiflora, Eria hyacinthoides, Aerides sp., Coelogyne sp., Dendrobium lineairifolium, Agrostophyllum sp., Sarcanthus sp., Flickingeria sp. and Eria monostachya. These epiphytic orchids used Dadap (Erythrina sp.), Jalina (Ficus sp.), Kukrup (Engelhardtia spicata) and Cempaka wangi (Michelia champaca) as host species, from Gate 1 to Gunung Mujur Point in UB Forest. Analysis showed that improvement including preserving and improving the population of host tree species, establishing interpretation media for educational purposes, and improving the attractiveness of tourist attractions and facilities, could provide an opportunity to develop an eco-tourism route.
\end{abstract}

Keywords: Ecotourism, Environmental education, Orchids

\section{INTRODUCTION}

Epiphytic orchids, Orchidaceae, form one of the biggest groups of plants which are abundant in tropical countries. In tropical forests, epiphytic orchids can grow on the surface of the main stem and the branches of plants. Many tree species with a canopy provide an ideal habitat for epiphytic orchids. A hot spot of epiphytic orchids is found in cloud forest, in which epiphytic orchids are in abundance in the tree canopy. Epiphytic orchids contribute significantly to ecological processes, especially in the function of the tree canopy. Disturbance of tropical forests, therefore, influences the existence of epiphytic orchids $[1 ; 2 ; 3]$.

Indonesian forests are home to numerous epiphytic orchid species. The diversity and abundance of orchids are especially relevant to tropical climatic conditions. The presence of high humidity level has obviously contributed to the high degree of diversity of orchids. The rich range of tree species and a huge canopy often provide ideal conditions for orchid growth. Orchids, especially epiphytic orchids, grow mostly on the stem and branches of trees [4].

Naturally and culturally, orchids are interesting objects and attract many visitors to a particular place to observe them. In an area with an abundance of orchids, identifying and

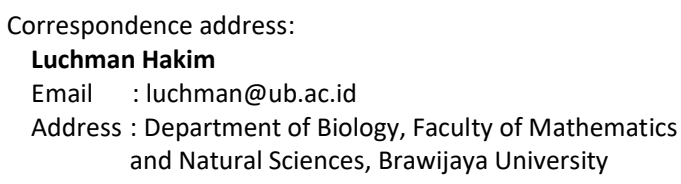

mapping the orchid habitat is a crucial step in developing an ecotourism attraction $[5 ; 6]$. This is particularly important in UB Forest, an educational forest in Malang, East Java. In such a case, however, determining the potential for orchids is important. Trees are critical for epiphytic orchids in a wild habitat. The aims of the research are to identify the species diversity of epiphytic orchids and their host tree species and to describe the perspectives of tourists on orchids as a nature-based tourism attraction in UB Forest.

\section{MATERIAL AND METHOD Study Area}

Fieldwork was done at UB Forest in Karangploso District, Malang Regency, in East Java Province (Figure1). In total, UB Forest covers an area of about 554 hectares; the dominant forest type is production forest. From the perspective of utilization and management, UB Forest is declared as Forest with Specific Purposes. UB forest plays an important role in biodiversity conservation and supporting local community wellbeing. It is also used as a facility for education.

\section{Floristic survey}

The survey was done along Corridor I of UB Forest, lengthwise from Gate 1 to Gunung Mujur Point. This corridor was selected for field observation because it is a potential tourist route for accessing many tourist attractions in UB Forest. The field survey was done from October 
2016 to March 2017 along $1.5 \mathrm{~km}$ of forest corridor.

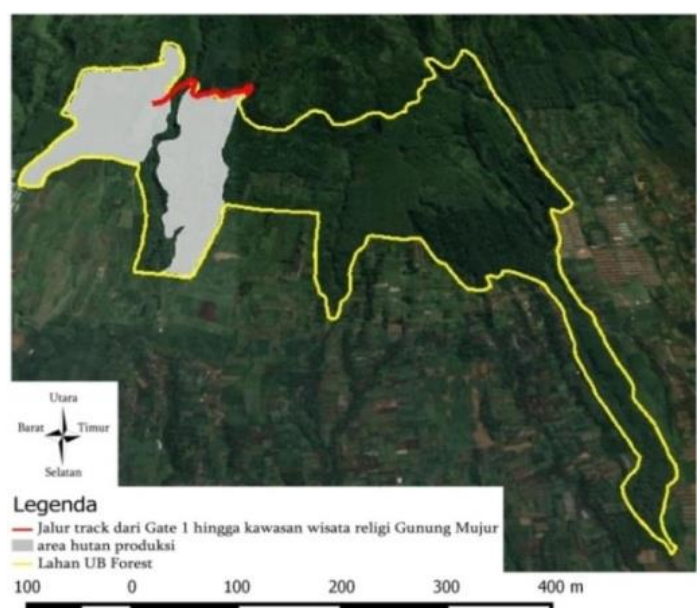

Figure 1. The position of UB Forest and the observation tract along Gate 1 to Gunung Mujur (in red line) (Google earth, 2016)

Plant tree species which were identified as hosts and habitats of epiphytic orchids were mapped and described. For each tree species, a survey of the epiphytic orchid species and the individual or population distribution of host tree species was made. Epiphytic orchids were identified by observing and identifying plant morphology using binoculars. An expert in orchid identification in the field from Purwodadi Botanical Garden was employed for species identification. Distribution of epiphytic orchids was classified according to zonation of epiphytic orchid distribution in host trees. There are five zones of epiphytic orchid distribution, namely Zone 1 on the basal stem of the tree, Zone 2 on the main stem of the tree, Zone 3 ina first-level branch or inner crown area, Zone 4 on a secondlevel branch or middle crown area, and Zone 5 on fork sites or outer crown area (Figure2).

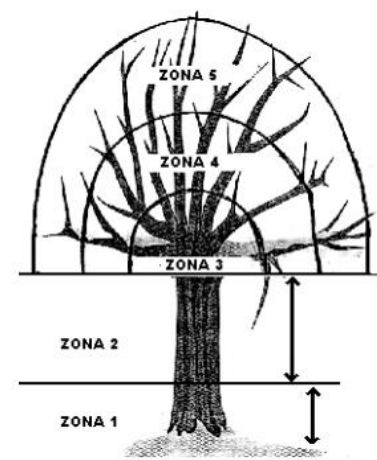

Figure 2. Zonation of epiphytes orchids distribution in host tree (Johanson, 1975)
Trees which have become a habitat for epiphytic orchids were mapped using GPS. The coordinates of trees and the elevation of sites were recorded by GPS. Data were stored in the GPS equipment, and transferred to a computer for further analysis.

\section{Questionnaire}

In order to get a vivid picture of tourist perception of epiphytic orchids as a tourist attraction along the corridor from Gate 1 to Gunung Mujur Point, a questionnaire was distributed to 70 people. The criteria for participants were: males and females in the age range $17-40$, who had visited UB Forest at least once within the past few years.

\section{Data Analysis}

Epiphytic orchid species diversity was analyzed descriptively following individual morphological characters and was compared with the standard orchid identification for Java Island [2]. Host tree species were analyzed descriptively according to plant morphological characters. Questionnaire data were analyzed using the formula:

$$
A i=\frac{(\mathrm{a} \times 5)+(\mathrm{b} \times 4)+(\mathrm{c} \times 3)+(\mathrm{d} \times 2)+(\mathrm{e} \times 1)}{a+b+c+d+e}
$$

$A i=$ perception score for question $i$

$\mathrm{a}=$ number of respondents with the answer $\mathrm{a}$

$\mathrm{b}=$ number of respondents with answer $\mathrm{b}$

$c \quad$ number of respondents with answer $c$

$\mathrm{d}=$ number of respondents with answer $\mathrm{d}$

$\mathrm{e}=$ number of respondents with answer $\mathrm{e}$

The result of the calculation was used to classify tourist perspectives into the following categories: $1<x<1.8$ (Strongly disagree), $1.81<x$ $<2.6$ (Disagree), $2.6<x<3.4$ (Neutral), $3.41<x$ $<4.2$ (Agree), $4.21<x<5$ (Strongly agree), or similar Likert-scale responses [7;8].

\section{RESULT AND DISCUSSION \\ Epiphytic Orchid Species Diversity}

Nine epiphytic orchid species were found along $1.5 \mathrm{~km}$ of UB Forest corridor from Gate 1 to Gunung Mujur Point.

\section{Liparisviridiflora (BI.) Lindl}

Liparis viridiflora grows in clumps on the surface of the host tree. It is characterized by a greenish white pseudobulb stem. Leaves green, opposite and oblong, with the leaf tip retuse. The 
distance between pseudobulb stem and leaf 4-5 $\mathrm{cm}$. Flowers were found in some individuals with a pale yellow color, with the flower position floslateralis. This species was found in Zones $1,3,4$ and 5 . No population was found in Zone 2 . This species is found on Java Island at an altitude of 300-1700 $\mathrm{m}$ asl., and in abundance at 450$1000 \mathrm{~m}$ asl [2].

\section{Eria hyacinthoides (BI.) Lindl}

Pseudobulbs very close together to build dense clump; brown to dark brown, 3-4 cm long. Leaves green, alternate, oblong, with the leaf tip obliquebifidate. No flowers found during observation. Quite common in UB Forest. The species was found in Zones 3,4 and 5.Globally, this species grows in India, Peninsular Malaysia, Sumatera, Bali, Kalimantan and New Guinea [2].

\section{Coelogyne sp.}

Sympodial, inflorescences at the terminal. Pseudobulb conspicuous, ovoid, with size $\pm 2-3$ $\mathrm{cm}$, dark yellow to green. Leaves linear, dark green, oblanceolate, apex shape obtuse with blade margin entire. Coelogyne sp. was found in Zones 3 and 4 . Flowers absent, leading to limited data to describe the proper name of species. Naturally, the distribution of Coelogyne includes a wide area including Thailand, Peninsular Malaysia, Java, Kalimantan, Philippines, Sulawesi and Maluku. It is commonly found at an altitude of $1500 \mathrm{~m}$ asl [2]

\section{Dendrobium linearifolium Teijsm. \& Binn}

Dendrobium linearifolium grows in clumps on the host tree, especially in Zones 2,3,4 and 5. Roots appear at the base of the pseudobulb to absorb nutrients on the surface of the stem. Pseudobulb oval, green to dark brown, fusiform, $4-5 \mathrm{~cm}$. Stem-likea needle, long, up to $15-20 \mathrm{~cm}$. Leaves dark, linear. Flower sepals white, and grow at the tip of the stem.

Dendrobium linearifoliumis distributed in South East Asia, Myanmar, Thailand, and Indonesia. It is often found in areas with long dry periods. It is commonly found in lowland areas< $500 \mathrm{~m}$ asl [2].

Eria monostachya Lindl

Grows in clumps. Stem dark brown, 5-10 $\mathrm{cm}$ long. Leaves green, alternate, oblong, long, leaf tip apex shape obtuse with blade margin entire. Rachis emerges and extends up to 20-30 $\mathrm{cm}$, and bears many flowers. Eria monostachya was found in Zone 4 . That this species is fairly common in Java. It is often found in mountainous areas [2].

\section{Agrostophyllum sp.}

Stem cylindrical, 10-15 cm long, dark green. Grows creeping with branched rhizomes. Leaves in opposite position along the stem, green to dark green, ovate, with blade margin entire. Flower small, white-yellowish, appears at the tip of the stem. Orchid clumps were found in Zones 3 and 5. The distribution of Agrostophyllum sp. in Papua New Guinea, Peninsular Malaysia, Sumatera, Java, Borneo, and the Philippines [2].

\section{Sarcanthus sp.}

Stem cylindrical, green pile, 15-20 cm long. Leaves green, alternate. Leaves have a needle-like appearance, long, 3-5 cm with blade margin entire. This genus was found in Zones 4 and 5.It has native distribution in Burma, New Guinea, and Australia. Only two species are found on Java Island [2].

\section{Aerides sp.}

Monopodial orchid with along stem. Leaves opposite, green, oblong, with blade margin entire and the tip of leaves emarginate. This orchid was found in Zones 3 and 4.Typically, this genus is common in lowland areas to $500 \mathrm{~m}$ asl. Aerides sp.is distributedin Sumatera, Java, Borneo, Sulawesi and Papua New Guinea.

\section{Flickingeria sp.}

Pseudobulb flat, size varies, yellowish green. Leaves green,4-8 cm long and 2-4 cm wide, oval, oblanceolate.

The second-level branch or middle crown area (Zone 4) and the outer crown area (Zone 5) were the main habitats for epiphytic orchids. The most abundant epiphytic orchid species was Liparis viridiflora. It accounted for $40 \%$ of all epiphytic orchids found in these zones. Eria hyacinthoides was abundant in Zone 4 . Ninety percent of all epiphytic orchids found in Zone 4 were Eria hyacinthoides. Aerides sp. was found in Zones 3 and 4 , about $50 \%$ in each, and was absent in Zones 1,2, and 5 . Ninety-five percent of Coelogyne sp. clumps observed grew in Zone 4, and only $5 \%$ grew in Zone 3 ; no Coelogyne sp. were found in Zones 1, 2 and 5. was found in Zone 4,and represented about $50 \%$ of all epiphytic orchid species counted. Agrostophyllum sp. was mostly found in Zone 5 . 


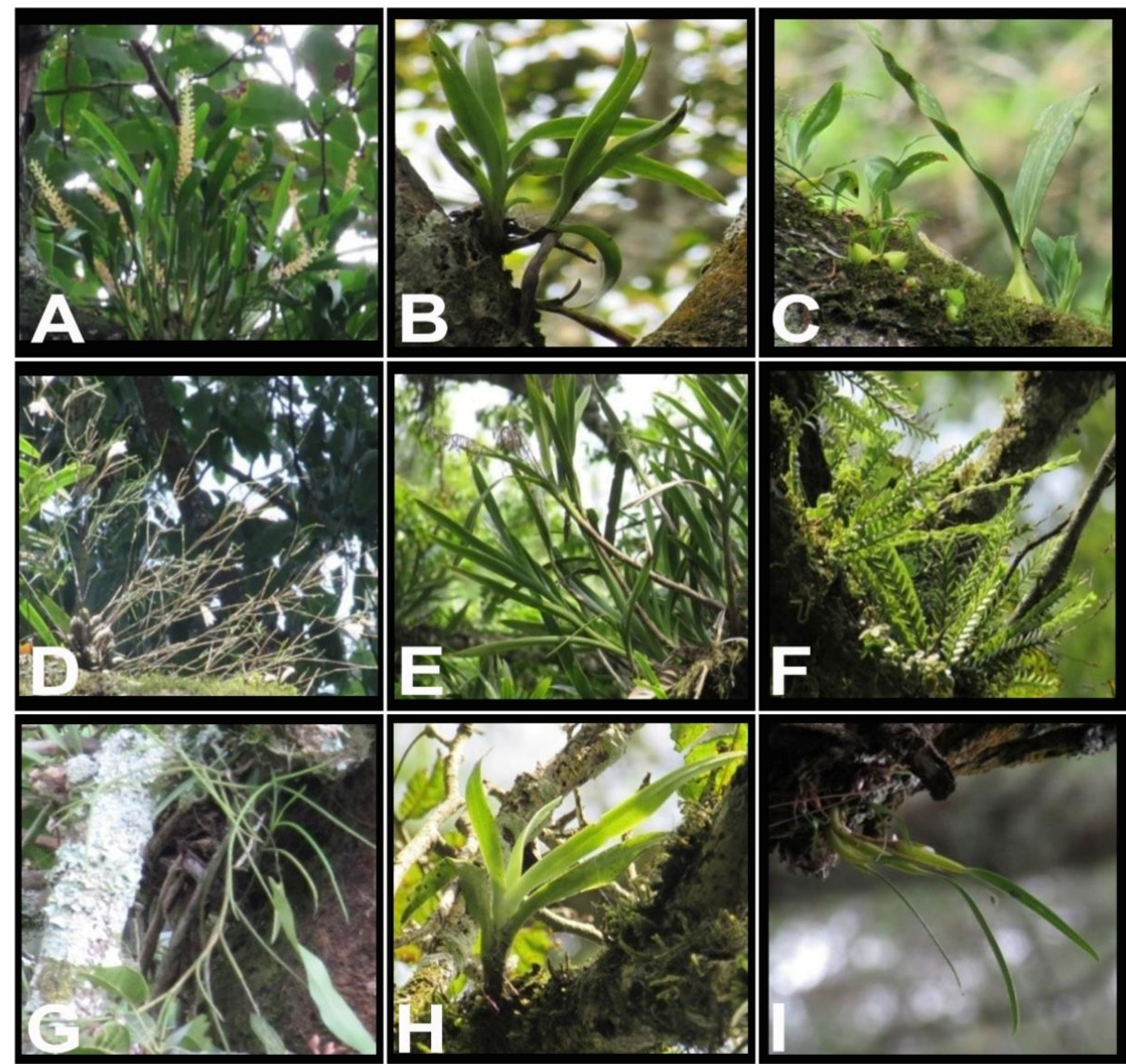

Figure3. Liparisviridiflora (A), Eriahyacinthoides (B), Coelogyne sp. (C), Dendrobiumlineariforium(D), Eriamonostachya (E), Agrostophyllum sp. (F), Sarchantus sp. (G), Aerides sp. (H),Flickingeria sp. (I)

The distribution of epiphytes orchids in host tree species was given in Fig. 4.

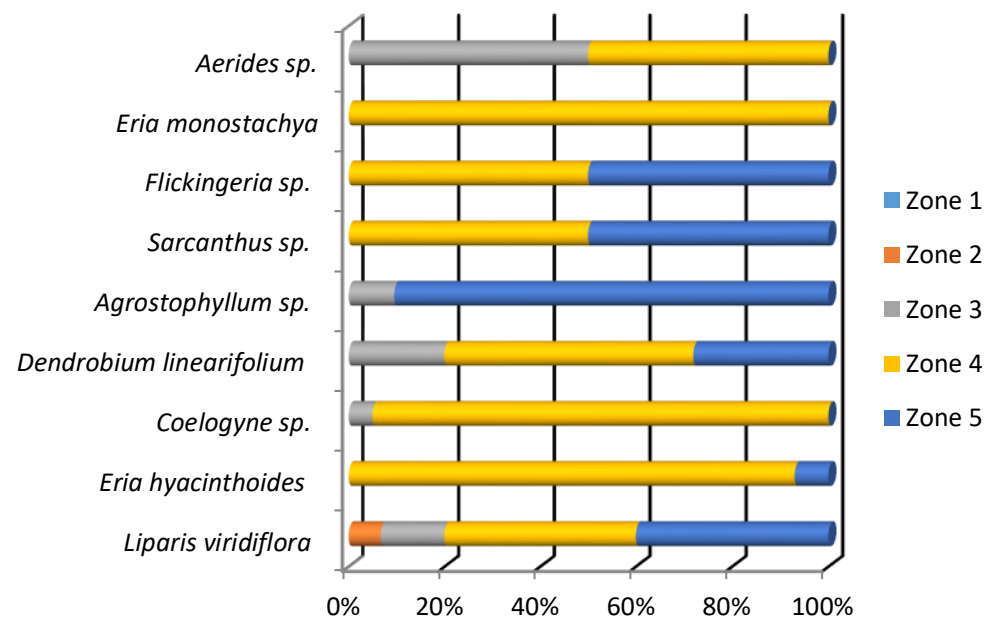

Figure 4. The total distribution of orchids following zones

About $90 \%$ of orchids in Zone 5 were Agrostophyllum sp. This taxon was also found in Zone 3 (10\% of all counted species). Sarcanthus sp. was found in Zones 4 and 5, 50\% in each zone. This species not found in Zones 1,2 and 3 . Flickingeria sp. was found in Zones 4 and 5, about 
$50 \%$ in each zone. This taxon was absent in Zones 1,2 and 3. Eria monostachyawas only found in Zone 4

Zone 4 has been identified as the main habitat for epiphytic orchids. This zone provides a potential habitat for orchids, since there is an abundance of organic debris, and it often has relatively high humidity to support epiphytic growth.Zones1, 2 and3 havea limited number of epiphytic orchids. The perpendicular position of the zoneseems to be a physical limitation factor for epiphytic growth $[9 ; 10]$.

\section{Host Tree Species}

Along the corridor from Gate 1 to Gunung Mujur Point, four species, namely Dadap (Erythrina sp., Fabaceae), Jalina or Beringin (Ficus sp., Moraceae), Kukrup (Engelhardtiaspicata, Juglandaceae) and Cempaka wangi (Michelia champaca, Magnoliaceae), were identified as habitats for epiphytic orchids. These plants were distributed at an altitude of 1224-1316 m asl.The species with the highest number of host trees were Engelhardtia spicata (42\%), followed by Michelia champaca (33\%), Erythrina sp. (17\%) and Ficus sp. (8\%).
Engelhardtia spicata is one of the crucial species components in a mountain forest plant community [11]. The geographic position of host trees and their habitus as host species are given in Table 1.A rough and cracked stem surface provides ideal sitesfor organic debris and water to collect, providing sustenance for epiphytic orchid growth.

The existence of few epiphytic orchid host tree species (Table 1 ) indicates past lowland forest disturbance in UB Forest. Recent dominant vegetation, Pinus, is unable to support epiphytic growth. These data indicate that efforts to introduce seedlings and new individuals and populations of native plant trees species are important to enhance epiphytic orchid conservation in UB Forest. This program will also potentially support the attractiveness of the forest road from Gate 1 to Gunung Mujur as an ecotourismroute.

\section{Tourist Perception of Orchids as A Tourist Attraction}

Respondentswere predominantly tourists in the range $20-22$ years old $(64.8 \%)$, followed by tourists $17-18$ years old (16.3\%), and those who were $22-23$ years old $(9.51 \%)$.

Table 1. Coordinates position of tree species as host of epiphytes orchids and stem morphological feature which are important to support epiphytes grows.

\begin{tabular}{|c|c|c|c|c|c|c|}
\hline \multirow[b]{2}{*}{ No. } & \multirow[b]{2}{*}{ Host Three Species } & \multicolumn{2}{|c|}{ Geographic Position } & \multicolumn{3}{|c|}{ Plant and Stem } \\
\hline & & Coordinate & Alt. (m asl) & $\begin{array}{l}\text { Plant Height } \\
\text { (m) }\end{array}$ & $\begin{array}{c}\text { Stem } \\
\text { Circumference }\end{array}$ & $\begin{array}{c}\text { Stem Surface/Bark } \\
\text { Type }\end{array}$ \\
\hline 1. & Michelia champaca & $\begin{array}{l}S: 7^{\circ} 49^{\prime} 28,3^{\prime \prime} \\
E: 112^{\circ} 34^{\prime} 45,3^{\prime \prime}\end{array}$ & 1224 & 35 & 340 & Rough, cracked \\
\hline 2. & Engelhardtia spicata & $\begin{array}{l}S: 7^{\circ} 49^{\prime} 29,6^{\prime \prime} \\
E: 112^{\circ} 34^{\prime} 48,1^{\prime \prime}\end{array}$ & 1239 & 33 & 300 & Cracked \\
\hline 3. & Michelia champaca & $\begin{array}{l}\text { S:7049'25,9" } \\
\text { E:112²34'43" }\end{array}$ & 1256 & 22 & 220 & Rough, cracked \\
\hline 4. & Michelia champaca & $\begin{array}{l}\text { S:7049'25,9" } \\
\text { E:112²34'48" }\end{array}$ & 1247 & 23 & 220 & Rough, cracked \\
\hline 5. & Michelia champaca & $\begin{array}{l}S: 7^{\circ} 49^{\prime} 24,8^{\prime \prime} \\
E: 112^{\circ} 34^{\prime} 49,3^{\prime \prime}\end{array}$ & 1241 & 36 & 500 & Rough, cracked \\
\hline 6. & Engelhardtia spicata & $\begin{array}{l}S: 7^{\circ} 49^{\prime} 22^{\prime \prime} \\
E: 112^{\circ} 34^{\prime} 51,1^{\prime \prime}\end{array}$ & 1288 & 32 & 280 & Cracked \\
\hline 7. & Engelhardtia spicata & $\begin{array}{l}\text { S:7049'25,3" } \\
\text { E:112²34'51,9" }\end{array}$ & 1316 & 35 & 300 & Cracked \\
\hline 8. & Engelhardtia spicata & $\begin{array}{l}\text { S:7049'25,3" } \\
E: 112^{\circ} 34^{\prime} 51,9^{\prime \prime}\end{array}$ & 1237 & 33 & 250 & Cracked \\
\hline 9. & Engelhardtia spicata & $\begin{array}{l}S: 7^{\circ} 49^{\prime} 30^{\prime \prime} \\
E: 112^{\circ} 34^{\prime} 43,7^{\prime \prime}\end{array}$ & 1268 & 37 & 400 & Cracked \\
\hline 10. & Ficus sp. & $\begin{array}{l}S: 7^{\circ} 49^{\prime} 26,3^{\prime \prime} \\
E: 112^{\circ} 35^{\prime} 6^{\prime \prime}\end{array}$ & 1251 & 40 & 300 & Scaly \\
\hline 11. & Erythrina sp. & $\begin{array}{l}\text { S: } 7^{\circ} 49^{\prime} 27,7^{\prime \prime} \\
\text { E:112 } 112^{\circ} 6,6^{\prime \prime}\end{array}$ & 1262 & 30 & 150 & $\begin{array}{l}\text { Peeling to smooth, } \\
\text { cracked }\end{array}$ \\
\hline 12. & Erythrina sp. & $\begin{array}{l}S: 7^{\circ} 49^{\prime} 27,6^{\prime \prime} \\
E: 112^{\circ} 35^{\prime} 6,5^{\prime \prime}\end{array}$ & 1277 & 25 & 175 & $\begin{array}{l}\text { Peeling to smooth, } \\
\text { cracked }\end{array}$ \\
\hline 13. & Michelia champaca & $\begin{array}{l}\text { S:7099'33,2" } \\
E: 112^{\circ} 35^{\prime} 25,8^{\prime \prime}\end{array}$ & 1262 & 20 & 180 & Rough, cracked \\
\hline
\end{tabular}


Only $2.8 \%$ of respondentswere aged $24 ; 14 \%$ of respondentswere 17 years old. About $5.19 \%$ did not mention their age; $39.2 \%$ of respondents were male and $60.8 \%$ were female.Respondents' perception of orchids as a tourist attraction and tourism-supporting system is given in Table 2 .

\section{Knowledge of Wild Orchids}

Questionnaire data analysis indicates that respondent's havelimited knowledge about wild orchids.Mostly, respondent's havetoo little knowledge to recognize the morphological characteristics of orchids, leading to poor abilityto identify the proper name of orchids (Table 1). There is an opportunity for UB Forest management to improve the education facility, to facilitate tourists' active learning in the field.

\section{Attractiveness of Orchids}

Orchids are attractive to the respondents (Table 1). The morphological aspectsof orchids and their population in a wild habitat are significant potential factors to attract visitors to UB Forest. The interest of respondents to explore orchids in the wild is principally similar to that reported for other areas [12;5]. In order to increase the attractiveness of orchids in a wild habitat, some aspects should be improved.

\section{Facilities}

Respondents think that the facilities should be improved. The accessibility of UB Forest and its safety should become crucial aspects in the improvement of the tourist facilities. Improvement of the tourist facilities is required to enhance tourist satisfaction, and in the context of ecotourism to increase the success of educational programs through field trips. It is important for the management of UB Forest to provide interpretation material along the tourist route. Interestingly, respondents argue that local community participation is important. This is important in ecotourism programs [5].

The recent status of orchids and their host tree species opens opportunities for further orchid tourism trails development for ecotourism programs. Orchid torism trails are corridors in which the education process can be facilitated by showing and explaining theepiphytic orchid diversity, both in their individual and ecosystem aspects.

In such a case, the introduction of new native forest tree species to act as future host species for epiphytic orchids is crucial. The number of new individuals of Erythrina sp., Ficus sp., Engelhardtia spicata and Michelia champaca could be increased.

Table 2. Knowledge, attractiveness and tourist perception of tourist facilities in UB Forest

\begin{tabular}{|c|c|c|c|}
\hline $\begin{array}{l}\text { No. } \\
\text { A. }\end{array}$ & Knowledge & $\mathbf{X}$ & Category \\
\hline 1. & Information regarding epiphytic orchids & 2.89 & Fair \\
\hline 2. & Ability to recognize orchids' morphological characteristics & 2.81 & Fair \\
\hline 3. & Ability to recognize and identify orchids from other epiphytes & 2.78 & Fair \\
\hline 4. & Know epiphytic orchids' habitat & 2.81 & Fair \\
\hline 5. & Know the benefits of epiphytic orchids & 2.66 & Fair \\
\hline B. & Attractiveness & & \\
\hline 1. & Have the interest to observe epiphytic orchids & 4.10 & Agree \\
\hline 2. & Orchids are beautiful flowers & 4.01 & Agree \\
\hline 3. & Orchids have potential value as a tourist attraction & 4.14 & Agree \\
\hline 4. & $\begin{array}{l}\text { The interesting part of orchids is individual structure, including } \\
\text { stem, leaf, and flower }\end{array}$ & 4.06 & Agree \\
\hline 3. & Accessibility of UB Forest as a recreation site & 2.97 & Satisfactory \\
\hline 4. & Attractiveness of tourist facilities & 2.61 & Good \\
\hline 5. & Improvement and establishment of new tourist attraction & 3.60 & Neither agree nor disagree \\
\hline 6. & Outdoor accommodation & 3.81 & Agree \\
\hline 7. & Homestay managed by local community & 2.89 & Neither agree nor disagree \\
\hline 8. & $\begin{array}{l}\text { Festival and exhibition related to orchid diversity and } \\
\text { conservation }\end{array}$ & 4.06 & Agree \\
\hline 9. & Improvement of UB Forest & 4.24 & Strongly agree \\
\hline 10. & Conformability of orchid observation point & 3.32 & Moderately satisfied \\
\hline 11. & Safety of orchid observation point & 3.39 & Somewhat concerned \\
\hline
\end{tabular}


Other potential species to introduce includeLithocarpus sundaicus, Trema orientalis, Macropanax dispermus, Actinodaphne procera, Castanopsis javanica, Syzygium sp. and Litsea sp. These species were found in a similar type of forest, Bromo Tengger Semeru Forest, as a habitat of epiphytic orchids [2;11;13].

Further exploration of the orchid species in the UB Forest area and the surrounding forest on Mt. Arjuno and Mt. Welirang is important to identify orchid species other than those reported in this study. These orchids should be introduced and integrated alongthe established ecotourism route from Gate 1 to Gunung Mujur.

\section{CONCLUSION}

Nine species of epiphytic orchids were found in UB Forest: Liparis viridiflora, Eria hyacinthoides, Aerides sp., Coelogyne sp., Dendrobium linearifolium, Agrostophyllum sp., Sarcanthus sp., Flickingeria sp. and Eria monostachya. Dadap (Erythrina sp.), Jalina (Ficus sp.), Kukrup (Engelhardtia spicata) and Cempaka wangi (Michelia champaca) are the hosts of the epiphytic orchid species. Orchids diversity and their host tree species open opportunities for further orchid tourism trail development for ecotourism programs. Improvements programs should be implemented, including preserving and improving the population of host tree species, establishing interpretation media for educational purposes, and improving the attractiveness of tourist attractions and facilities

\section{ACKNOWLEDGEMENT}

The authors thank to the Brawijaya University for facilitating this research.

\section{REFERENCES}

[1]. Johansson, D. R. (1975). Ecology of epiphytic orchids in West African rain forests. American Orchid Society Bulletin, 44(22), 125-136.

[2]. Comber, J. B. (1990). Orchids of Java. Kew: Bentham-Moxon Trust, Royal Botanic Gardens.

[3]. Cribb, P. J., Kell, S. P., Dixon, K. W., \& Barrett, R. L. (2003). Orchid Conservation: A Global Perspective. Orchid Conservation, (January), 1-24.

[4]. Kull, T., \& Arditti, J. (2013). Orchid Biology VIII: Reviews and Perspectives. Heidelberg: Springer Science \& Business Media.

[5]. Pradhan, K. C. (2005). Orchids and poverty alleviation through eco-tourism in the
Sikkim Himalayas. In the 17th World Orchid Conference: Sustaining Orchids for the Future 2002 (pp. 153-157). Selangor (Malaysia): Natural History Publications (Borneo) Sdn Bhd.

[6]. Prener, H. (2005). Orchids and eco-tourism: the world natural heritage and biosphere reserve, Huanglong. In the 17th World Orchid Conference: Sustaining Orchids for the Future 2002 (pp. 158-164). Selangor (Malaysia): Natural History Publications (Borneo) Sdn Bhd.

[7]. Vagias, W. M. (2006). Likert-Type Scale Response Anchors - A listing of standardized ratings for evaluation. Clemson International Institute for Tourism \& Research Development, Department of Parks, Recreation and Tourism Management. Clemson University., 4-5. https://doi.org/10.1525/auk.2008.125.1.22 5.

[8]. Hakim, L. (2014). Etnobotani dan Manajemen Kebun-Pekarangan Rumah: Ketahanan Pangan, Kesehatan, dan Agrowisata. Malang, Indonesia: Penerbit Selaras.

[9]. Adhikari, Y. P., Fischer, H. S., \& Fischer, A. (2012). Host tree utilization by epiphytic orchids in different land-use intensities in Kathmandu Valley, Nepal. Plant Ecology, 213(9),1393-1412. https://doi.org/10.1007/ s11258-012-0099-0.

[10]. Benzing, D. H. (2008). Vascular Epiphytes: General Biology and Related Biota. Cambridge: Cambridge University Press.

[11]. Hakim, L., \& Miyakawa, H. (2013). Plant trees species for restoration program in Ranupani , Bromo Tengger Semeru National Park Indonesia. Biodiversity Journal, 4(3), 387-394.

[12]. Ballantyne, M., \& Pickering, C. (2012). Ecotourism as a threatening process for wild orchids. Journal of Ecotourism, 11(1), 3447. https://doi.org/10.1080/14724049.20 11.628398.

[13]. Nurfadilah, S. (2015). Diversity of Epiphytic Orchids and Host Trees ( Phorophytes) in Secondary Forest of Coban Trisula, Malang Regency, East Java ,. Biotropia, 22(2), 120128. https://doi.org/10.11598/btb.2015. 22. 2.450 . 